IZA DP No. 6456

Legislative Term Limits and State Aid to Local Governments

Pavel A. Yakovlev

Mehmet S. Tosun

William P. Lewis

March 2012 


\title{
Legislative Term Limits and State Aid to Local Governments
}

\author{
Pavel A. Yakovlev \\ Duquesne University
}

Mehmet S. Tosun

University of Nevada, Reno and IZA

William P. Lewis

Duquesne University

\section{Discussion Paper No. 6456 \\ March 2012}

\author{
IZA \\ P.O. Box 7240 \\ 53072 Bonn \\ Germany \\ Phone: +49-228-3894-0 \\ Fax: +49-228-3894-180 \\ E-mail: iza@iza.org
}

\begin{abstract}
Any opinions expressed here are those of the author(s) and not those of IZA. Research published in this series may include views on policy, but the institute itself takes no institutional policy positions.

The Institute for the Study of Labor (IZA) in Bonn is a local and virtual international research center and a place of communication between science, politics and business. IZA is an independent nonprofit organization supported by Deutsche Post Foundation. The center is associated with the University of Bonn and offers a stimulating research environment through its international network, workshops and conferences, data service, project support, research visits and doctoral program. IZA engages in (i) original and internationally competitive research in all fields of labor economics, (ii) development of policy concepts, and (iii) dissemination of research results and concepts to the interested public.
\end{abstract}

IZA Discussion Papers often represent preliminary work and are circulated to encourage discussion. Citation of such a paper should account for its provisional character. A revised version may be available directly from the author. 


\section{ABSTRACT}

\section{Legislative Term Limits and State Aid to Local Governments}

We estimate the effect of legislative term limits on various categories of state government spending using the most recent panel of 47 states from 1972 to 2005 . Besides the usual economic, political, fiscal and demographic factors, we also control for the state tax and expenditure limitations. We find that term limits have a significant positive effect on total state government spending, but no significant positive effect on state education, health, transportation or welfare expenditures. This dichotomy in the estimates raises a very important and previously overlooked question: what budget category is responsible for higher state spending in term-limited states? Our analysis reveals that legislative term limits increase pork-barrel spending, which takes the form of higher transfers from state to local governments. This finding might also imply that legislative term limits lead to more fiscal decentralization.

JEL Classification: $\quad \mathrm{H} 7, \mathrm{H} 3$

Keywords: term limits, pork-barrel spending, rent-seeking, transportation, welfare, education, health, intergovernmental aid and transfers

Corresponding author:

Pavel Yakovlev

Department of Economics and Quantitative Sciences

Duquesne University

600 Forbes Avenue

Pittsburgh, PA 15282

USA

E-mail: yakovlevp@duq.edu

\footnotetext{
* We would like to thank Justin Ross, Saurav Roychoudhury, and Colleen Donovan for helpful comments and suggestions.
} 


\section{Introduction}

Since 1990, twenty U.S. states have adopted legislative term limits, but six of these states later repealed them. At the time of their passage, legislative term limits were virtually an untested experiment. ${ }^{1}$ Prior to 1990 , it was a common practice to impose term limits on state executive office, but not on state legislature. The widespread adoption of state legislative term limits in the United States has spurred a bourgeoning scholarly literature on their behavioral and fiscal effects. A pertinent string of research documents a significant positive association between the level of state spending and the enactment of legislative term limits. However, our analysis of the most recent data leads to a puzzling observation: legislative term limits appear to have a significant positive effect on total state spending but no such effect on the major components of state spending such as education, welfare, health, and transportation. If states with term-limited legislators spend more money, then what do they spend it on? We conduct a thorough literature review, which is followed by an empirical analysis that reveals the likely culprit responsible for higher spending: state aid to local governments.

We contribute to the existing literature on term limits by utilizing a more recent dataset and controlling for state tax and expenditure limitations (TELs), a potentially important factor in limiting government spending. A panel data analysis of 47 U.S. states from 1972 to 2004 shows that term limits lead to significantly higher transfers in constant dollars per capita from state to local governments. We hypothesize that this rise in pork-barrel spending occurs because term limits turn legislators into more transient creatures of the political wilderness. Another interesting implication is that term limits give rise to more local control on public service provision.

\footnotetext{
${ }^{1}$ The proposal to impose term limits on federal legislators was ruled by the Supreme Court to be unconstitutional (U.S. Term Limits, Inc. v. Thornton, 1995).
} 
The paper is structured as follows. In the next section we discuss the relevant empirical literature. We provide a detailed description of data in section 3, which is followed by our empirical approach and estimates in section 4. In section 5, we discuss the robustness of our findings. In the remaining section, we offer concluding remarks and ideas for future research.

\section{Literature Review}

Populating public offices with transient-minded politicians, as a direct consequence of term limits, has important implications for the type of fiscal policies these legislators will implement. The adoption of legislative term limits by several U.S. states in the 1990s has generated a large and diverse amount of scholarly literature, which we attempt to survey in this section.

Proponents of term limits argue that limiting the number of terms a legislator can serve in office would usher in a new era of "citizen legislators" who are more concerned with serving the interests of the voters than their own political careers (Will 1992). In light of the welldocumented incumbency advantage (Kalt and Zupan 1984, 1990; Matsusaka 1992; Biglaiser and Mezzetti 1997; Berry et al. 2000; Yakovlev 2007, 2011), term limits are popularly viewed as a way to relinquish the hold of incumbents on state offices and make legislators more accountable to their constituents. Proponents also claim that shorter tenure in office leads to less pork-barrel spending (Will 1992; Payne 1992; Carey et al. 1998).

However, many recent studies find these arguments unconvincing (Lopez 2001). Because politicians are self-interested agents (Kreuger 1974), term limits may succeed in preventing them from holding the same office rather than end political careerism. In fact, term-limited legislators have a tendency to move from office to office (Carey et al. 1998; Sarbaugh-Thompson et al. 2004). Thus, term limits appear to produce a new breed of transient career politicians who use 
the legislative office as a stepping-stone for further political advancement. Several studies also note that legislative term limits are associated with a decline in the relative power of the legislative branch (Kousser 2005; Moncrief and Thompson 2001; Peery and Little 2002; Carey et al. 2006).

Furthermore, term limits can make legislators less accountable to their constituents. The "lame duck" shirking argument postulates that soon to be ex-legislators find it advantageous to legislate in a manner that is inconsistent with their constituents' preferences given the lack of reelection incentives (Tien 2001). Acemoglu et al. (2011) find that term limits can exacerbate the populist bias in policies (i.e. ideological shirking occurs). Term limited legislators are also less likely to participate in roll-call votes, which is indicative of participatory shirking (Wright 2007). However, if incumbent politicians really care about their party reputations, then the "lame duck" shirking argument loses support (Besley and Case, 1995, 2003; Smart and Sturm, 2006; Alt, de Mesquita and Rose, 2011; Ferraz and Finan, 2011). Nevertheless, several studies find evidence of increased ideological shirking in the presence of term limits (Rothenberg and Sanders 2000; Lott and Bronars 1993; Besley and Case 1995; Carey 1996; Carey et al. 2006).

Another string of research points out that term limits can lead to more pork-barrel spending and larger government size. A theoretical model by Herron and Shotts (2006) predicts that when pork-barrel projects are very wasteful, term limits can actually increase pork-barrel spending to benefit politicians' districts. Cadot et al. (2006) find that rent-seeking legislators enact more pork-barrel spending in the form of higher public welfare expenditures. Gamm and Kousser (2010) hypothesize that higher legislative turnover rates would lead to a higher percentage of district-level bills introduced, which could lead to more pork-barrel spending that benefits local districts. However, their analysis of 165,000 bills from thirteen different states over 
the last 120 years does not support their claim. Besley and Case (1995) find that Democratic governors in the United States tax and spend more when they face binding term limits. Johnson and Crain (2004) find that term limits lead to a steady increase in government size over time. Erler (2007) finds that legislative term limits have a significant positive effect on transportation, welfare, health, and total state spending, but not on education spending. Alt et al. (2011) find that economic growth is higher, while taxes, spending, and borrowing costs are lower under reelection-eligible incumbents compared to term-limited incumbents.

A related string of research shows that term-limits also make legislators more shortsighted in their fiscal decisions. Hefner et al. (1990) argues that the transient nature of office holding under term limits forces legislators spend more on the projects with short-term payoffs and less on the projects with long-term payoffs. Examining capital outlay expenditures from 1969 to 1987 , Hefner et al. find that capital outlays are inversely related to public welfare expenditures. Garri (2009) argues that term limits seem to exacerbate the already existing bias in political behavior that favors short-term policy solutions, an effect he calls political "shorttermism". Cummins (2008) theorizes that states with term-limited legislatures should have a harder time managing its fiscal policies for two reasons. First, term limits would produce inexperienced legislators who are ill-equipped to make complex fiscal policy decisions. Second, term limited politicians are likely to have a shortsighted perspective on state finances. Cummins finds that states with term limits are more likely to run year-end general fund balances that are on average $2 \%$ lower compared to states without term limits. Similarly, Donovan (2010) estimates that term limits at the local government level exacerbate fiscal impatience. Ironically, it appears that term limits create outcomes that are often opposite of what their proponents hope to achieve. 
There is also a closely related literature on tax and expenditure limitations (TEL), which are similarly thought to be ways to limit the size of state and local governments. Earlier studies did not find a strong negative impact of TELs on the size of state and local governments (Joyce and Mullins 1991; Mullins and Joyce 1996; Skidmore 1999; Mullins and Wallin 2004), which is explained (at least from a revenue perspective) by the substitution of restricted revenue instruments with unrestricted ones. More recent studies went beyond the mere existence of TELs by quantifying the restrictiveness of these measures (Poulson 2005; Bae and Gais 2007; Amiel et al. 2009; Nicholson-Crotty and Theobald 2011; Bae and Jung 2011; Stallman and Deller 2011, Deller et al. 2012a, Deller et al. 2012b). Amiel et al. (2009) argue that TELs are very heterogeneous, which makes the use of dummy variables measuring the adoption and existence of TELs rather problematic. They construct a TEL index based on the following characteristics: type of TELs in terms of specific revenue and/or expenditure coverage; whether the TEL is statutory or constitutional; growth restrictions such as population, personal income changes and inflation; approval method of the TEL; override provisions and exemptions. Studies using the Amiel et al. index typically find that TELs have a negative effect on education, welfare and transportation (Nicholson-Crotty and Theobald 2011; Deller et al. 2012b). Consequently, we use the TEL index developed by Amiel et al. (2009) as an important control variable in our regression model.

\section{Data}

We utilize a longitudinal panel of 47 U.S. states from 1972 to 2005 to estimate the effect of state legislative term limits on various categories of state spending such as general expenditures, education, transportation, welfare, heath, and aid to local governments. Like Erler 
(2007), we exclude Alaska, Hawaii, and Nebraska from our sample. Erler (2007) argues that the fiscal structures of Alaska and Hawaii are unique and incomparable to the other states, necessitating their exclusion as outliers. Nebraska is excluded because of its unicameral system of government.

Our dataset contains more recent observations compared to previous studies, specifically by Erler. This is a very important distinction considering that many term limits were passed in the 1990s but became binding or effective only several years after their passage, mainly after 2000. For example, Oklahoma passed term limit legislation in 1990, but the first group of its legislators was banned from running for reelection only in 2004. Several states that enacted term limits also repealed them a few years later before they went into effect (Idaho, Utah, Massachusetts, Oregon, Washington, and Wyoming). For this reason, considering term limits being effective at the time of their adoption (as in Erler) is very problematic given that the legislators in the states that repealed term limits might have expected this outcome. Given the probability of repeal, it can be argued that term limits should have a credible behavioral effect on the legislators only when they become binding (i.e. force the fist cohort of legislators out of office). Therefore, our term limit dummy equals one in years when term limits become binding and zero otherwise. States that adopted and afterwards repealed term limits and states that never had term limits have the term limit dummy variable set equal to zero for the entire time period. Only the following twelve states are treated as having binding or effective term-limits in our dataset: Arizona, Arkansas, California, Colorado, Florida, Maine, Michigan, Montana, Missouri, Ohio, Oklahoma, and South Dakota.

Furthermore, not all term limits are equal in their stringency. Some states have longer (shorter) term limits and some have lifetime (consecutive) restrictions on re-election as shown in 
Table 1. To control for these differences in term limit stringency, we use term length (in years) and lifetime ban (dummy) variables. Our intuition suggests that the presence of term limits and lifetime bans on re-election should have a positive effect on state expenditures, while longer term length (i.e. less severe term limit) should have a negative effect on state expenditures.

[Table 1 about here]

In estimating the effect of term limits on state fiscal policies, we examine similar expenditure categories as in Erler (2007): general expenditures, transportation, welfare, health, and education. We also examine all other sizeable categories in state budgets, particularly state aid to local governments and school districts. Economic theory and previous research (Erler 2007; Cummins 2008; Alt and Lowrey 1994; Besley and Case 2003; Knight 2000, 2002; Matsusaka 1995; Poterba 1994, 1997; Reed 2006; Joyce and Mullins 1991; Mullins and Joyce 1996; Mullins and Wallin 2004; Stallman and Deller 2011) suggest the following control variables: federal aid to the states, gross state product, unemployment rate, population density, percentage of elderly population, state tax and expenditure limitations, divided government, governor term limits, and political party in charge.

[Table 2 about here]

Table 2 provides a list of the variables used in this study and their summary statistics. The variance inflation test shows no alarming multicollinearity among our explanatory variables (results are available from the authors upon request). Much of our data is collected from publicly available sources such as the U.S. Census Bureau, Statistical Abstract of the United States, Fiscal Survey of the States, State Government Tax Collections, Bureau of Economic Analysis, and the Book of the States. The index of state tax and expenditure limitations is provided by 
Amiel et al. (2009). The index ranges from 0 to 30, where higher values indicate more restrictive TELs.

\section{Empirical Model and Estimates}

Following Erler (2007), we estimate the effect of binding term limits on various categories of state government spending using an OLS procedure with two-way fixed-effects and panel-corrected standard errors (PCSE). Beck and Katz (1995) recommend using PCSE in the presence of group-wise heteroskedasticity, autocorrelation, and contemporaneous correlation (all of which were detected in our panel dataset). According to Beck and Katz (1995), PCSE outperforms FGLS when sample size is finite and T is less than N, which is the case in our study. The proposed panel data model is:

$$
G_{i t}=\alpha+\gamma T_{i t}+\delta L_{i t}+\sum_{j=1}^{9} \beta_{j} X_{i t}+u_{i}+v_{i}+\varepsilon_{i t}
$$

Where $G_{i t}$ is state government expenditure in constant dollars per capita, $\alpha$ is a constant, $T_{i t}$ is the term-limit dummy, $L_{i t}$ is term length in years, $X_{i t}$ is a vector of typical control variables used in the literature, $u_{i}$ is state fixed effects (dummies), $v_{t}$ is year fixed effects (dummies), and $\varepsilon_{i t}$ is the error term. Using this model, we estimate the effect of term limits on the following categories of state government spending: general expenditures, education, transportation, welfare, health, other general expenditures, state aid to local governments, and many others.

In Table 3, we report the PCSE estimates for the five categories of state expenditures: general, education, transportation, welfare, and health. The estimates in the first column in Table 3 show that term limits have a significant positive effect on general expenditures, confirming Erler's (2007) original finding. Also, the allotted term length has a significant negative effect on general expenditures, which makes intuitive sense considering that the longer legislators are allowed to remain in office the less term limits should matter. Holding everything else equal, our 
estimates indicate that states with term limits spend, on average, 465 dollars more per person than states without term limits and that every additional year of term length reduces general expenditures per person by 59 dollars. The estimates in the first column also show that tax and expenditure limits have a significant negative effect on general expenditures, which is consistent with several recent studies on TELs. The estimates also show that GDP, federal aid to states, and unemployment rate have a significant positive effect on general expenditures.

[Table 3 about here]

In contrast, the remaining columns in Table 3 reveal that term limits and term lengths have no statistically significant effect on education, welfare, health, or transportation expenditures. Both our and Erler's empirical models appear to be less successful in explaining the variations in specific categories of state spending compared to total state spending. Erler acknowledges the lack of theoretical foundations for specific state expenditure categories and recommends more research in this area. In contrast to our estimates though, Erler finds a significant positive effect of term limits on transportation and health (at 5\%) and weakly significant positive effect of term limits on education (at 10\%). The difference between our and Erler's estimates can be attributed to different time periods used (Erler uses 1977-2001) and different term limit coding (Erler counts term limits at the time passed).

A comparison of term limit coefficients across different expenditure categories begs the question: if term-limited states spend more in total, but not in the four major budget categories, then what do they spend it on? If term-limited states do not spend significantly more on education, transportation, welfare, and health, then they must be spending the money elsewhere. In Table 4, we estimate the effect of term limits and term lengths on the remaining portion of general expenditures (i.e. the difference between general expenditures and the sum of welfare, 
education, transportation, and health expenditures). According to the estimates in the first column of Table 4, term limits and term lengths have a stronger impact on the remaining portion of general expenditures than total expenditures.

\section{[Table 4 about here]}

These estimates make us wonder which budget category is responsible for this result. After estimating the effect of term limits on every sizeable budget category, we have identified the likely culprit: state aid to local governments. State aid, much of which goes to school districts, is the only specific expenditure category that appears to be positively and significantly affected by term limits. Our analysis of the relevant literature suggests that this is not a coincidence. For instance, Gamm and Kousser (2010) argue that a higher turnover rate in state legislature, an effect similar to term limits, should lead to a higher percentage of district-oriented bills. Although Gamm and Kousser do not find empirical support for this claim, their hypothesis sounds reasonable to us. Legislators must face much stronger pork-barrel spending incentives when their terms in office are numbered because they often go back to their districts in search of future employment opportunities. The pork-barrel incentive must be especially strong in states with lifetime term-limits because state legislatures cannot return to their state office, forcing them to look for future public office positions in their home districts, where they often get elevated to a hero status because of their pork-barrel accomplishments. In term-limited states, this cycle continues with predictable frequency, resulting in more pork-barrel spending as a way to appease the district's constituents. According to this logic, one might expect more pork-barrel spending (i.e. more state transfers to local governments) to occur in states with term-limited legislators, ceteris paribus. 
The estimates in column 2 of Table 4 indicate that term limits increase state aid to local governments by 298 dollars per capita, confirming the pork-barrel hypothesis. This marginal effect amounts to about $60 \%$ of the coefficient size for term limit's impact on the remaining general expenditures (see column 1, Table 4). The estimate for term limits in column 2 in Table 4 appears to be within a reasonable range considering that there is $\$ 113$ difference in aid per capita between term-limited and non term-limited states during the 1996-2005 period. The estimates in column 2 also suggest that each year of term length decreases state transfers to local governments by 39 dollars per capita. The model also reveals that GDP and federal aid to states have a significant positive effect on the transfers to local governments, while population density and the percentage of elderly population have a significant negative effect on the transfers to local governments. It is encouraging that the empirical model produces a negative estimate for the elderly population variable, which is consistent with the literature on the intergenerational conflict in school financing (Poterba 1997, Tosun et al. 2011). The state aid model in Table 4 performs much better empirically in comparison to the four expenditure categories in Table 3.

A potential issue of concern in these estimates is reverse causality between state aid and term limits. It could be argued that term limit adoption is motivated, in part, by previous state aid levels. If this is true, then the estimated positive coefficient for term limits implies that the causality runs in the opposite direction: from state aid to term limits. For this assertion to be true, the states that adopted term limits must have had higher levels of state transfers to local governments than the states without term limits. However, the state aid trends shown in Figure 1 indicate that the opposite is true: states with term limits had lower levels of state aid to local governments than states without term limits prior to 1990s, when many states began adopting term limits. However, by the early 2000s, when many term limits became effective, term-limited 
states appear to have caught up to or even exceeded non term-limited states in state aid per capita. According to our calculations, the average state aid to local governments was $\$ 1,259$ per capita in states with effective term limits compared to $\$ 1,146$ per capita in states without term limits during 1996-2005.

[Figure 1 about here]

Figure 1 suggests that term limits are not endogenous in state spending levels. Similarly, Knight (2000) and Matsusaka (1995) also argue that term limits are likely to be exogenous to spending levels because term limit adoption seems to be more collinear with citizen initiative processes rather than voters' fiscal preferences. Erler (2007) and Donovan (2010) argue that term limit adoption appears to be motivated by the desire to limit the incumbency advantage and promote a new class of "citizen-legislators" rather than voters' concerns about government size.

Although it is likely that term limits are exogenous, we estimate a dynamic, system GMM model developed by Arellano and Bover (1995) and Blundell and Bond (1998) in order to alleviate concerns about potential endogeneity bias. According to Roodman (2006), a dynamic GMM estimator is well suited for the following circumstances: (1) linear hypothesis testing; (2) few time periods and many cross sections; (3) autoregressive dependent variable; (4) independent variables not being strictly exogenous; (5) time-invariant fixed effects; and (6) heteroskedasticity and autocorrelation. The aforementioned issues are rather descriptive of our situation. In our dynamic, system GMM model, term limits and term lengths are instrumented with lagged values or differences of the dependent and independent variables. The GMM estimates shown in column 3 in Table 4 are qualitatively similar to the OLS-PCSE estimates that treat term limits as exogenous. The GMM estimates reveal that term limits have a significant positive effect on state aid to local governments, while term length has a significant negative 
effect on state aid to local governments.

\section{Robustness Checks}

In this section, we perform robustness checks to ensure that our results are not spurious. We re-estimate the models in Table 3 and 4 using conventional two-way fixed effects OLS with robust standard errors and two-way fixed effects OLS with Driscoll and Kraay robust standard errors. Driscoll and Kraay (1998) developed a nonparametric covariance matrix estimator that produces heteroscedasticity consistent standard errors, which are also robust to general forms of spatial and temporal dependence. Both of these techniques tell a similar story (albeit with larger coefficient magnitudes): term limits increase general expenditures, other general expenditures, and state aid to local governments (see Tables 5-7). ${ }^{2}$ In comparison, the PCSE and GMM estimates of term limits appear to be more conservative.

[Table 5 about here]

[Table 6 about here]

[Table 7 about here]

As an additional robustness check, we also check for outlier bias and drop some control variables in order to expand our dataset to cover a larger time period from 1970 to 2006. Dropping the variables with missing observations also makes this larger panel fully balanced. In addition, we add a dummy variable indicating the presence of lifetime term limits. Lifetime limits turn out to have a significant positive effect on state aid to local governments, as expected. Despite all of these alterations, the estimates for the effect of term limits and term lengths on state aid to local governments remain qualitatively similar to those reported in Table 4 and are

\footnotetext{
${ }^{2}$ The coefficient for TELs in the general expenditures model is still negative but no longer statistically significant. However, the coefficient for TELs in the education and healthcare spending models is negative and statistically significant in both Table 5 and 6, which is similar to the finding by Deller et al. (2012b).
} 
available upon request from the authors. As an additional check, we interacted term limits with the TEL restrictiveness index to see if these policy measures have a combined effect on state government expenditures. We did not find significant changes in the term limits coefficients and the interaction term did not turn up significant.

\section{Conclusion}

Previous research has shown that states with legislative term limits exhibit higher levels of state government spending, holding everything else constant. In this study, we analyze the latest available data and confirm this positive association between legislative term limits and total state government spending. However, our analysis reveals that the four main categories of state expenditures (welfare, education, transportation, and health) appear to be unaffected by legislative term limits. The logical question arises: what drives the overall increase in state spending if not the four main categories of state expenditures?

A thorough review of the relevant literature suggests that term-limited legislators face stronger incentives to enact pork-barrel policies that benefit their districts. We examine numerous categories of state government spending that are large enough to account for much of the observed increase in total state spending and find that state aid to local governments is the only state expenditure category that appears to be significantly affected by legislative term limits. This result persists across different estimation techniques and after controlling for tax and expenditure limitations, demographic, economic, state and year fixed effects. Our estimates suggest that despite similar expected outcomes, term limits and tax and expenditure limitations have opposite impacts on general government expenditures. Our estimates indicate that state aid to local governments is large enough to account for much of the increase in total state spending. 
More research is still warranted in understanding the local government behavior in response to increased state aid. We recommend more theoretical and empirical research on the relative effectiveness of term limits compared to tax and expenditure limitations. 


\section{References}

Acemoglu, Daron, Georgy Egorov, and Konstantin Sonin. 2011. "A Political Theory of Populism.” NBER Working Paper 17306.

Alt, J., \& Lowry, R. 1994. "Divided government, fiscal institutions, and budget deficits: Evidence from the states." American Political Science Review, 88: 811-828.

Alt, J., E. B. de Mesquita, and S. Rose. 2011. "Disentangling Accountability and Competence in Elections: Evidence from U.S. Term Limits.” Journal of Politics, 73 (1): 171-186.

Amiel, Lindsay, Steven Deller and Judith Stallmann. 2009. "The Construction of a Tax and Expenditure Limitation Index for the US." University of Wisconsin Agricultural and Applied Economics Staff Paper Series No. 536, May 2009, 33p. http://www.aae.wisc.edu/pubs/sps/

Arellano, M., and S. Bond. 1991. "Some tests of specification for panel data: Monte Carlo evidence and an application to employment equations," Review of Economic Studies, 58: 277-297.

Arellano, M., and O. Bover. 1995. "Another look at the instrumental variable estimation of errorcomponents models," Journal of Econometrics, 68: 29-51.

Bae, Suho and Thomas Gais. 2007. "The Effects of State-Level Tax and Expenditure Limitations on Revenues and Expenditures," Rockefeller Institute Policy Brief.

Bae, Suho and Changhoon Jung. 2011. "The Effects of Tax and Expenditure Limitation (TEL) Stringency on the Local Expenditure and Revenue," International Review of Administrative Sciences, 77 (4): 647-669.

Barro, Robert J. 1979. "On the Determination of the Public Debt," The Journal of Political Economy, 87(5): 940-971.

Beck, Nathaniel and Jonathan Katz. 1995. "What to do (and not to do) with Time-Series CrossSection Data." The American Political Science Review, 89 (3): 634-647.

Berry, William; Michael Berkman and Stuart Schneiderman. 2000. "Legislative Professionalism and Incumbent Reelection: The Development of Institutional Boundaries." The American Political Science Review, 94(4): 859-874.

Besley, Timothy and Anne Case. 1995. "Does Electoral Accountability Affect Economic Policy Choices? Evidence fro Gubernatorial Term Limits." The Quarterly Journal of Economics, 110(3): 769-798.

Besley, T., \& Case, A. 2003. "Political institutions and policy choices: Evidence from the United States." Journal of Economic Literature, 41: 7-73.

Biglaiser, Gary and Claudio Mezzetti., 1997. "Politicians' decision making with re-election concerns." Journal of Public Economics, 66 (3), 425-447.

Blundell, R., Bond, S., 1998. Initial conditions and moment restrictions in dynamic panel data models. Journal of Econometrics 87, 115-143.

Cadot, Olivier, Lars-Hendrik Roller and Andreas Stephan. 2006. "Contribution to Productivity or Pork Barrel?” Journal of Public Economics, 90: 1133-1153.

Carey, John. 1996. Term Limits and Legislative Representation. Cambridge University Press, New York, NY.

Carey, John; Richard Niemi and Lynda Powell. 1998. "The Effects of Term Limits on State Legislatures." Legislative Studies Quarterly, 23(2): 271-300.

Carey, J. M., R. G. Niemi, L. W. Powell, G. F. Moncrief. 2006. "The Effects of Term Limits $\square$ on 
State Legislatures: $\square$ A New Survey of the 50 States" Legislative Studies Quarterly, XXXI, 1: 105-134.

Cummins, Jeff. 2008. "Term Limits, Electoral Competition and the Impact on State Fiscal Conditions.” Working Paper. Western Political Science Association Annual Conference; San Diego, CA.

Deller, Steve, Judith Stallman and Lindsay Amiel. 2012a. "The Impact of State and Local Tax and Expenditure Limitations on State Economic Growth." Growth and Change, 43 (1): 56-84.

Deller, Steve, Judith Stallman and Lindsay Amiel. 2012b. "Does the Restrictiveness of State Tax and Expenditure Limitations Affect State Revenues and Expenditures?" Manuscript.

Donovan, Colleen. 2010. "Direct democracy, term limits, and fiscal decisions in U.S. municipalities." Paper presented at the 49th Annual Meeting of the Western Regional Science Association, Sedona, AZ.

Driscoll, J. C., and A. C. Kraay. 1998. Consistent Covariance Matrix Estimation with Spatially Dependent Panel Data. Review of Economics and Statistics 80: 549-560.

Erler, Abbie H. 2007. "Legislative Term Limits and State Spending." Public Choice, (133): 479494.

Ferraz, Claudio and Frederico Finan. 2011. "Electoral Accountability and Corruption: Evidence from the Audits of Local Governments." American Economic Review, 101 (4): 12741311.

Friedman, Milton. 1957. A Theory of the Consumption Function. Princeton Univ Press. ISBN 13 978-0691041827.

Gamm, Gerald and Thad Kousser. 2010. "Broad Bills or Particularistic Policy? Historical Patterns in American State Legislatures." American Political Science Review, 104 (1): 151-170.

Garri, Iconio. 2009. "Political Short-Termism: a Possible Explanation." Public Choice, published online. http://www.springerlink.com/content/j0k412wq74t72qn3/ (accessed November 20, 2009).

Hall, Robert. 1978. "Stochastic Implications of the Life Cycle-Permanent Income Hypothesis: Theory and Evidence" The Journal of Political Economy, 86(6): 971-987.

Hefner, Frank L. and Timothy E. Burson. 1990. "The Determinants of Regional Infrastructure Spending.” Working Paper. The Annual North American Regional Science Meetings, Boston, MA.

Herron, Michael C. and Kenneth W. Shotts. 2006. "Term Limits and Pork," Legislative Studies Quarterly, 31 (3): 383-403.

Holtz-Eakin Douglas, Harvey S. Rosen, and Schuyler Tilly. 1994. "Intertemporal Analysis of State and Local Government Spending: Theory and Tests,"Journal of Urban Economics, 35 (2): 159-174.

Johnson, J., and W. Crain. 2004. "Effects of Term Limits on Fiscal Performance: Evidence from Democratic Nations." Public Choice, 119, 73-90.

Joyce, Philip G. and Daniel Mullins. 1991. "The Changing Fiscal Structure of the State and Local Public Sector: The Impact of Expenditure Limitations," Public Administration Review, 51 (3): 240-253.

Kalt, Joseph P. and Mark A. Zupan. 1984 "Capture and Ideology in the Economic Theory of Politics," American Economic Review, 74: 279-300.

Kalt, Joseph P and Mark A Zupan. 1990. “The Apparent Ideological Behavior of Legislators: 
Testing for Principal-Agent Slack in Political Institutions", Journal of Law and Economics, 33(1):103-131.

Knight, B. G. 2000. "Supermajority voting requirements for tax increases: Evidence from the states." Journal of Public Economics, 76, 41-67.

Knight, B. G. 2002. "Endogenous federal grants and crowd-out of state government spending: Theory and evidence from the Federal Highway Aid program." American Economic Review, 92: 71-92.

Kousser, Thad. 2005. Term Limits and the Dismantling of State Legislative Professionalism. Cambridge, UK: Cambridge University Press.

Kreuger, A.O. 1974. "The Political Economy of the Rent-Seeking Society," American Economic Review, 64: 291-303.

Lott, John and Stephen Bronars. 1993. "Time Series Evidence on Shirking in the U.S. House of Representatives." Public Choice, 76:125-149.

Lopez, Edward J., 2001. Term Limits: Causes and Consequences. Public Choice, Forthcoming. Available at SSRN: http://ssrn.com/abstract=278844

Matsusaka, John G. 1992. "Economics of Direct Legislation," Quarterly Journal of Economics, 107(2): 541-571.

Matsusaka, John G. 1995. "Fiscal Effects of the Voter Initiative: Evidence from the Last 30 Years," Journal of Political Economy, 103(3): 587-623.

Moncrief, Gary and Joel A. Thompson. 2001. "Lobbyists' Views on Term Limits". Spectrum: Journal of State Government, 74 (4): 13-15.

Mullins, Daniel and Philip Joyce. 1996. "Tax and Expenditure Limitations and State and Local Fiscal Structure: An Empirical Assessment.” Public Budgeting and Finance, 16 (1): 75 101.

Mullins, Daniel and B.A. Wallin. 2004. "Tax and Expenditure Limitations: Introduction and Overview," Public Budgeting and Finance, Winter: 2-15.

Nicholson-Crotty, S. and N. Theobald. 2011. "Claiming Credit in the U.S. Federal System: Testing a Model of Competitive Federalism," Publius: The Journal of Federalism, 41 (2): 232-256.

Payne, J. 1992. The Culture of Spending: Why Congress Lives Beyond Our Means. San Francisco: ICS Press.

Peery, George, and Thomas H. Little. 2002. "Leading When the Bell Tolls: Perceptions of Power among Termed and Untermed Leaders." In The Test of Time: Coping 134 John M. Carey et al. with Legislative Term Limits, ed. Rick Farmer, John David Rausch, and John C. Green. Lexington, MA: Lexington Books.

Poterba, J. M. 1994. "State responses to fiscal crises: the effects of budgetary institutions and politics." The Journal of Political Economy, 102: 799-821.

Poterba, J. M. 1997. "Demographic structure and the political economy of public education." Journal of Policy Analysis and Management, 16: 48-66.

Poulson, B. 2005. "Grading the States' Tax and Expenditure Limits: A Fiscal Discipline Report Card," Americans for Prosperity Foundation.

Reed, R. W. 2006. "Democrats, republicans, and taxes: Evidence that political parties matter." Journal of Public Economics, 90: 725-750.

Rothenberg, Lawrence and Mitchell Sanders. 2000. "Severing the Electoral Connection: Shirking in the Contemporary Congress." Midwest Political Science Association, 44(2): 316-325. 
Roodman, D., 2006. How to Do xtabond2: An Introduction to "Difference" and "System" GMM in Stata. Working Paper Number 103. Center for Global Development.

Sarbaugh-Thompson, Majorie; Lyke Thompson, Chales Elder, John Strate, and Richard Elling. 2004. Political and Institutional Effects of Term Limits.

Skidmore, Mark. 1999. "Tax and Expenditure Limitations and the Fiscal Relationships between State and Local Governments." Public Choice, 99 (1-2): 77-102

Smart, Michael, and Daniel M. Sturm. 2006. "Term Limits and Electoral Accountability.” LSE PSPE Working Paper No.3.

Stallman, Judith and Steven Deller. 2011. "State Tax and Expenditure Limitations, Business Climate, and Economic Performance." Public Budgeting and Finance, 31 (4): 109-135.

Tien, Charles. 2001. "Representation, Voluntary Retirement, and Shirking in the Last Term," Public Choice, 106: 117-130.

Tosun, M., Williamson, C. and P. Yakovlev. 2011. "Elderly Migration and Education Spending: Intergenerational Conflict Revisited," Public Budgeting and Finance, Forthcoming.

Will, G. F. 1992. Restoration: Congress, Term Limits, and the Recovery of Deliberative Democracy. New York: Free Press.

Wright, G. C. 2007. "Wright Do Term Limits Affect Legislative Roll Call Voting? Representation, Polarization, and Participation" State Politics and Policy Quarterly, 7(3): 256-280

Yakovlev, Pavel. 2007. "Ideology, Shirking, and the Incumbency Advantage in the U.S. House of Representatives." Economics Bulletin, 4(33): 1-6.

Yakovlev, Pavel. 2011. "In uncertainty we trust: a median voter model with voter risk aversion" Financial Theory and Practice, 4: 466-477. 
Table 1. Distribution and Characteristics of State Legislative Term Limits

\begin{tabular}{|c|c|c|c|c|}
\hline & Year Passed & Year of Impact & $\begin{array}{c}\text { Term Length } \\
\text { (House/Senate) }\end{array}$ & $\begin{array}{l}\text { Lifetime } \\
\text { Ban }\end{array}$ \\
\hline Arizona & 1992 & 2000 & $8 / 8$ & No \\
\hline Arkansas & 1992 & 1998 & $6 / 8$ & Yes \\
\hline California & 1990 & 1996 & $6 / 8$ & No \\
\hline Colorado & 1990 & 1998 & $8 / 8$ & No \\
\hline Florida & 1992 & 2000 & $8 / 8$ & No \\
\hline Idaho* & 1994 & - & - & - \\
\hline Louisiana & 1995 & 2007 & $12 / 12$ & No \\
\hline Maine & 1993 & 1996 & $8 / 8$ & No \\
\hline Massachusetts* & 1994 & - & - & - \\
\hline Michigan & 1992 & 1998 & $6 / 8$ & Yes \\
\hline Missouri & 1992 & 2002 & $8 / 8$ & Yes \\
\hline Montana & 1992 & 2000 & $8 / 8$ & No \\
\hline Nevada & 1996 & 2010 & $12 / 12$ & Yes \\
\hline Ohio & 1992 & 2000 & $8 / 8$ & No \\
\hline Oklahoma & 1990 & 2004 & $12 / 12$ & Yes \\
\hline Oregon* & 1992 & - & - & - \\
\hline South Dakota & 1992 & 2000 & $8 / 8$ & No \\
\hline Utah* & 1994 & - & - & - \\
\hline Washington* & 1992 & - & - & - \\
\hline Wyoming* & 1992 & - & - & - \\
\hline
\end{tabular}

Source: National Conference of State Legislatures. *These states repealed term limits before they went into effect: Idaho in 2002, Massachusetts in 1997, Oregon in 2002, Utah in 2003, Washington in 1998, Wyoming in 2004. States without effective (binding) term limits between 1972 and 2005 are excluded from the empirical analysis. 
Table 2. Variable Descriptions and Summary Statistics.

\begin{tabular}{|c|c|c|}
\hline Variable & Variable Description & $\begin{array}{c}\text { Mean } \\
\text { (Std. Dev.) }\end{array}$ \\
\hline $\begin{array}{l}\text { General } \\
\text { expenditures }\end{array}$ & $\begin{array}{l}\text { General state expenditures (comprises all other expenditures except for } \\
\text { liquor store, utility, and insurance trust) in constant dollars per capita. }\end{array}$ & $\begin{array}{l}3,046 \\
(908)\end{array}$ \\
\hline Transportation & Infrastructure (capital) outlays in constant dollars per capita. & $\begin{array}{c}331 \\
(133)\end{array}$ \\
\hline Welfare & Public welfare expenditures in constant dollars per capita. & $\begin{array}{c}603 \\
(315)\end{array}$ \\
\hline Education & Public education expenditures in constant dollars per capita. & $\begin{array}{l}965 \\
(286)\end{array}$ \\
\hline Health & Public health expenditures in constant dollars per capita. & $\begin{array}{l}215 \\
(86)\end{array}$ \\
\hline Other expenditures & $\begin{array}{l}\text { General expenditures minus education, transportation, health and } \\
\text { welfare spending, in constant dollars per capita. }\end{array}$ & $\begin{array}{c}931 \\
(626)\end{array}$ \\
\hline $\begin{array}{l}\text { State aid to local } \\
\text { governments }\end{array}$ & $\begin{array}{l}\text { State government transfers to local governments in constant dollars per } \\
\text { capita. }\end{array}$ & $\begin{array}{c}920 \\
(351)\end{array}$ \\
\hline Term limit & $\begin{array}{l}\text { Dummy variable indicating the presence of binding term limits for } \\
\text { state legislators }(1=\text { term limit, } 0=\text { otherwise }) \text {. }\end{array}$ & $\begin{array}{c}0.05 \\
(0.21) \\
\end{array}$ \\
\hline Term length & $\begin{array}{l}\text { Number of years state legislators can hold office before being forced } \\
\text { out by term limits in state. }\end{array}$ & $\begin{array}{c}0.35 \\
(1.60)\end{array}$ \\
\hline Lifetime limit & $\begin{array}{l}\text { Dummy variable indicating the presence of lifetime ban on re-election } \\
\text { of term-limited state legislators }(1=\text { lifetime ban, } 0=\text { otherwise }) .\end{array}$ & $\begin{array}{l}0.019 \\
(0.14)\end{array}$ \\
\hline $\begin{array}{l}\text { Tax \& expenditure } \\
\text { limits }\end{array}$ & $\begin{array}{l}\text { Index of state tax and spending limits (higher values mean stricter } \\
\text { limits; range: } 0 \text { to } 30 \text { ). }\end{array}$ & $\begin{array}{c}5.24 \\
(7.26)\end{array}$ \\
\hline GDP & Gross state product per capita in constant dollars. & $\begin{array}{l}31,173 \\
(6931)\end{array}$ \\
\hline Federal aid & Federal government transfers to states in constant dollars per capita. & $\begin{array}{c}887 \\
(367)\end{array}$ \\
\hline Unemployment rate & Percent unemployed. & $\begin{array}{c}5.93 \\
(1.97)\end{array}$ \\
\hline Population $65+$ & Percent of population 65 years old and over. & $\begin{array}{c}0.12 \\
(0.02)\end{array}$ \\
\hline Population density & Population density (people per square mile). & $\begin{array}{l}145.8 \\
(187.1)\end{array}$ \\
\hline $\begin{array}{l}\text { Divided } \\
\text { government }\end{array}$ & $\begin{array}{l}\text { Dummy variable indicating divided political control of legislative and } \\
\text { executive branches }(1=\text { divided, } 0=\text { otherwise }) \text {. }\end{array}$ & $\begin{array}{c}0.53 \\
(0.50)\end{array}$ \\
\hline Governor democrat & Dummy variable for governor democrat $(1=$ democrat, $0=$ otherwise $)$ & $\begin{array}{c}0.54 \\
(0.50)\end{array}$ \\
\hline $\begin{array}{l}\text { Governor lame } \\
\text { duck }\end{array}$ & $\begin{array}{l}\text { Dummy variable for governor in last term }(1=\text { lame duck, } 0= \\
\text { otherwise). }\end{array}$ & $\begin{array}{c}0.26 \\
(0.44)\end{array}$ \\
\hline
\end{tabular}

Notes: Like Erler (2007), we drop Alaska and Hawaii from our sample due to their atypical budgetary process (these states are definite outliers) and Nebraska due to its unicameral legislature (no party control variable is available for Nebraska). All variables vary across states and time. 
Table 3. The Effect of Term Limits on State Expenditures: 1972-2005.

\begin{tabular}{|c|c|c|c|c|c|}
\hline & $\begin{array}{c}\text { General } \\
\text { expenditures }\end{array}$ & Welfare & Transportation & Education & Health \\
\hline Estimator & OLS-PCSE & OLS-PCSE & OLS-PCSE & OLS-PCSE & OLS-PCSE \\
\hline Term limit & $\begin{array}{c}465.3 * * * \\
(156.1)\end{array}$ & $\begin{array}{l}-54.96 \\
(124.3)\end{array}$ & $\begin{array}{c}37.19 \\
(33.14)\end{array}$ & $\begin{array}{c}123.7 \\
(110.4)\end{array}$ & $\begin{array}{c}9.77 \\
(32.41)\end{array}$ \\
\hline Term length & $\begin{array}{c}-58.67 * * * \\
(20.53)\end{array}$ & $\begin{array}{c}5.60 \\
(16.16)\end{array}$ & $\begin{array}{l}-1.90 \\
(4.18)\end{array}$ & $\begin{array}{l}-16.01 \\
(13.33)\end{array}$ & $\begin{array}{l}-0.90 \\
(3.80)\end{array}$ \\
\hline $\begin{array}{l}\text { Tax \& expenditure } \\
\text { limits }\end{array}$ & $\begin{array}{l}-2.54 * * \\
(1.22)\end{array}$ & $\begin{array}{c}-1.21 * * \\
(0.62)\end{array}$ & $\begin{array}{l}-0.26 \\
(0.37)\end{array}$ & $\begin{array}{l}-0.70 \\
(0.63)\end{array}$ & $\begin{array}{l}-0.07 \\
(0.25)\end{array}$ \\
\hline GDP & $\begin{array}{l}0.02 * * * \\
(0.004)\end{array}$ & $\begin{array}{c}0.003 \\
(0.002)\end{array}$ & $\begin{array}{c}0.004 * * * \\
(0.001)\end{array}$ & $\begin{array}{l}0.0011 \\
(0.002)\end{array}$ & $\begin{array}{c}0.0001 \\
(0.0001)\end{array}$ \\
\hline Federal aid & $\begin{array}{c}0.70 * * * \\
(0.05)\end{array}$ & $\begin{array}{c}0.31 * * * \\
(0.02)\end{array}$ & $\begin{array}{c}0.08 * * * \\
(0.02)\end{array}$ & $\begin{array}{c}0.02 \\
(0.03)\end{array}$ & $\begin{array}{l}0.02 * * \\
(0.01)\end{array}$ \\
\hline Unemployment rate & $\begin{array}{c}10.94 * * \\
(4.85)\end{array}$ & $\begin{array}{l}5.10 * * \\
(2.47)\end{array}$ & $\begin{array}{c}1.92 \\
(1.53)\end{array}$ & $\begin{array}{c}1.37 \\
(2.66)\end{array}$ & $\begin{array}{l}-0.91 \\
(0.80)\end{array}$ \\
\hline Population $65+$ & $\begin{array}{c}289.0 \\
(409.6)\end{array}$ & $\begin{array}{c}117.3 \\
(144.9)\end{array}$ & $\begin{array}{c}60.64 \\
(178.6)\end{array}$ & $\begin{array}{c}-493.8 * * \\
(225.6)\end{array}$ & $\begin{array}{c}119.8 \\
(77.68)\end{array}$ \\
\hline Population density & $\begin{array}{c}0.08 \\
(0.95)\end{array}$ & $\begin{array}{l}-0.63 \\
(0.46)\end{array}$ & $\begin{array}{l}0.57 * * \\
(0.23)\end{array}$ & $\begin{array}{l}-0.43 \\
(0.41)\end{array}$ & $\begin{array}{l}-0.04 \\
(0.12)\end{array}$ \\
\hline Divided government & $\begin{array}{l}10.23 \\
(8.73)\end{array}$ & $\begin{array}{c}1.09 \\
(3.86)\end{array}$ & $\begin{array}{c}5.4839 * \\
(2.87)\end{array}$ & $\begin{array}{l}-1.24 \\
(4.46)\end{array}$ & $\begin{array}{l}-0.71 \\
(1.52)\end{array}$ \\
\hline Governor democrat & $\begin{array}{l}11.28 \\
(9.89)\end{array}$ & $\begin{array}{l}-2.27 \\
(4.37)\end{array}$ & $\begin{array}{l}-0.30 \\
(3.13)\end{array}$ & $\begin{array}{c}1.50 \\
(5.63)\end{array}$ & $\begin{array}{c}0.43 \\
(1.71)\end{array}$ \\
\hline Governor lame duck & $\begin{array}{c}3.16 \\
(8.81)\end{array}$ & $\begin{array}{c}9.09 * * \\
(4.48)\end{array}$ & $\begin{array}{l}-2.51 \\
(3.00)\end{array}$ & $\begin{array}{l}-1.44 \\
(4.87)\end{array}$ & $\begin{array}{c}1.52 \\
(1.38)\end{array}$ \\
\hline State fixed effects & Yes & Yes & Yes & Yes & Yes \\
\hline Year fixed effects & Yes & Yes & Yes & Yes & Yes \\
\hline
\end{tabular}


Table 4. The Effect of Term Limits on State Expenditures: 1972-2005.

\begin{tabular}{lccc}
\hline & $\begin{array}{c}\text { Other } \\
\text { expenditures }\end{array}$ & $\begin{array}{c}\text { State aid to local } \\
\text { governments }\end{array}$ & $\begin{array}{c}\text { State aid to local } \\
\text { governments }\end{array}$ \\
\hline Estimator & OLS-PCSE & OLS-PCSE & System GMM \\
\hline Term limit & $492.5^{* * *}$ & $297.5^{* * *}$ & $247.6^{* * *}$ \\
& $(163.2)$ & $(102.9)$ & $(107)$ \\
Term length & $-64.83^{* * *}$ & $-38.48^{* * *}$ & $-28.4^{* * *}$ \\
& $(19.44)$ & $(12.35)$ & $(13.9)$ \\
Tax \& expenditure limits & -0.23 & 0.05 & 0.08 \\
& $(0.73)$ & $(0.65)$ & $(1.05)$ \\
GDP & $0.01^{* * *}$ & $0.005^{* *}$ & $0.01^{* * *}$ \\
& $(0.003)$ & $(0.002)$ & $(0.001)$ \\
Federal aid & $0.23^{* * *}$ & $0.12^{* * *}$ & $0.10^{* * *}$ \\
& $(0.03)$ & $(0.03)$ & $(0.04)$ \\
Unemployment rate & 3.85 & 3.75 & 2.81 \\
& $(3.27)$ & $(2.78)$ & $(3.37)$ \\
Population 65+ & 430.3 & $-543.2^{*}$ & -128.4 \\
& $(354.4)$ & $(284.3)$ & $(354.7)$ \\
Population density & 0.78 & $-1.54 * * *$ & 0.05 \\
& $(0.60)$ & $(0.41)$ & $(0.08)$ \\
Divided government & 3.75 & 1.69 & -4.94 \\
& $(6.57)$ & $(5.07)$ & $(8.9)$ \\
Governor democrat & 4.94 & 0.19 & 0.49 \\
& $(6.55)$ & $(5.99)$ & $(6.6)$ \\
Governor lame duck & -3.34 & 0.12 & -2.07 \\
& $(6.78)$ & $(4.95)$ & $(6.9)$ \\
Lagged dependent variable & - & - & $0.8 * * *$ \\
State fixed effects & Yes & Yes & $(0.04)$ \\
Year fixed effects & Yes & Yes & - \\
\hline & Yes \\
\hline
\end{tabular}

Notes: Robust standard errors in parentheses. Constant and fixed effects coefficients are not reported. *** Indicates significance at $1 \%, * *$ indicates significance at 5\%, * indicates significance at 10\%. Term limit and term length variables in system GMM are treated as endogenous and instrumented with lagged values or differences of dependent and independent variables. 
Table 5. The Effect of Term Limits on State Expenditures: 1972-2005.

\begin{tabular}{lccccc}
\hline & $\begin{array}{c}\text { General } \\
\text { expenditures }\end{array}$ & Welfare & Transportation & Education & Health \\
\hline Estimator & OLS & OLS & OLS & OLS & OLS \\
\hline Term limit & $1,010^{* *}$ & -502.4 & -19.31 & -21.31 & 55.65 \\
& $(403.3)$ & $(333.0)$ & $(73.47)$ & $(246.6)$ & $(113.7)$ \\
Term length & $-132.9 * *$ & 57.08 & 4.75 & 2.56 & -6.10 \\
Tax \& expenditure & $(57.29)$ & $(42.09)$ & $(10.40)$ & $(29.78)$ & $(14.25)$ \\
limits & -1.52 & -1.19 & 0.06 & $-2.6 *$ & 1.3 \\
GDP & $(3.1)$ & $(1.53)$ & $(0.82)$ & $(1.42)$ & $(1.13)$ \\
& $0.04^{* * *}$ & $0.006^{*}$ & $0.006 * * *$ & 0.002 & 0.002 \\
Federal aid & $(0.01)$ & $(0.003)$ & $(0.001)$ & $(0.003)$ & $(0.002)$ \\
& $0.88^{* * *}$ & $0.43^{* * *}$ & $0.08^{* * *}$ & -0.04 & 0.05 \\
Unemployment rate & $(0.12)$ & $(0.12)$ & $(0.03)$ & $(0.06)$ & $(0.03)$ \\
& 12.70 & 4.21 & -0.28 & 0.69 & -0.47 \\
Population 65+ & $(11.42)$ & $(4.82)$ & $(3.51)$ & $(5.58)$ & $(2.29)$ \\
Population density & 563.9 & -184.9 & 280.1 & -1732 & 433.3 \\
Divided government & $(1,862.7)$ & $(828)$ & $(409.8)$ & $(1,103.9)$ & $(544.6)$ \\
& -1.46 & -0.94 & 0.29 & -0.43 & -0.12 \\
Governor democrat & $(1.15)$ & $(0.89)$ & $(0.33)$ & $(0.76)$ & $(0.31)$ \\
Governor lame duck & $41.36 * *$ & $18.9 * *$ & $11.71 * *$ & 9.99 & 4.35 \\
State fixed effects & $(18.69)$ & $(8.35)$ & $(4.95)$ & $(10.36)$ & $(5.06)$ \\
Year fixed effects & 13.76 & 4.08 & -7.8 & 17.67 & 0.61 \\
\hline Notes: & $(22.14)$ & $(8.87)$ & $(5.63)$ & $(12.66)$ & $(7.23)$ \\
& 5.72 & -3.47 & -1.13 & -0.65 & $-8.67 *$ \\
& $(14.37)$ & $(10.13)$ & $(5.64)$ & $(8.5)$ & $(4.85)$ \\
& Yes & Yes & Yes & Yes & Yes \\
& Yes & Yes & Yes & Yes & Yes \\
\hline
\end{tabular}

Notes: Robust standard errors in parentheses. Constant and fixed effects coefficients are not reported. *** Indicates significance at $1 \%, * *$ indicates significance at $5 \%, *$ indicates significance at $10 \%$. 
Table 6. The Effect of Term Limits on State Expenditures: 1972-2005.

\begin{tabular}{|c|c|c|c|c|c|}
\hline & $\begin{array}{c}\text { General } \\
\text { expenditures }\end{array}$ & Welfare & Transportation & Education & Health \\
\hline Estimator & OLS-DK & OLS-DK & OLS-DK & OLS-DK & OLS-DK \\
\hline \multirow{2}{*}{ Term limit } & $1010.0 * * *$ & $-502.4 * * *$ & -19.31 & -21.31 & 55.65 \\
\hline & $(219.1)$ & $(92.91)$ & $(59.18)$ & $(75.53)$ & $(52.26)$ \\
\hline \multirow{2}{*}{ Term length } & $-132.9 * * *$ & $57.08 * * *$ & 4.750 & 2.563 & -6.104 \\
\hline & $(29.14)$ & $(12.28)$ & $(7.346)$ & $(9.579)$ & $(6.437)$ \\
\hline Tax \& expenditure & -1.515 & -1.191 & 0.0611 & $-2.596 * * *$ & $1.295 * * *$ \\
\hline limits & $(2.190)$ & $(0.809)$ & $(0.208)$ & $(0.749)$ & $(0.404)$ \\
\hline \multirow{2}{*}{ GDP } & $0.0361 * * *$ & $0.00546 * *$ & $0.00584 * * *$ & 0.00171 & $0.0019 * * *$ \\
\hline & $(0.00396)$ & $(0.00233)$ & $(0.000810)$ & $(0.00235)$ & $(0.00034)$ \\
\hline \multirow{2}{*}{ Federal aid } & $0.877 * * *$ & $0.434 * * *$ & $0.0781 * * *$ & -0.0439 & $0.0475^{* * *}$ \\
\hline & $(0.0737)$ & $(0.0536)$ & $(0.0221)$ & $(0.0341)$ & $(0.0152)$ \\
\hline \multirow{2}{*}{ Unemployment rate } & 12.70 & 4.209 & -0.281 & 0.685 & -0.473 \\
\hline & $(9.933)$ & $(5.033)$ & $(1.786)$ & $(4.228)$ & $(0.675)$ \\
\hline \multirow{2}{*}{ Population $65+$} & 563.9 & -184.9 & 280.1 & $-1732 * * *$ & 433.3 \\
\hline & $(1316.5)$ & $(411.0)$ & $(235.8)$ & $(524.7)$ & $(307.9)$ \\
\hline \multirow{2}{*}{ Population density } & $-1.464 * *$ & $-0.942 * * *$ & $0.287 * *$ & $-0.427 *$ & $-0.124 *$ \\
\hline & $(0.598)$ & $(0.299)$ & $(0.133)$ & $(0.236)$ & $(0.0730)$ \\
\hline \multirow{2}{*}{ Divided government } & $41.36 * * *$ & $18.90 * *$ & $11.71 * * *$ & 9.992 & 4.345 \\
\hline & $(11.29)$ & $(7.571)$ & $(2.951)$ & $(7.881)$ & $(3.681)$ \\
\hline \multirow{2}{*}{ Governor democrat } & 13.76 & 4.078 & -7.800 & $17.67 *$ & 0.611 \\
\hline & $(12.60)$ & $(10.11)$ & $(5.596)$ & $(9.837)$ & $(4.976)$ \\
\hline \multirow{2}{*}{ Governor lame duck } & 5.718 & -3.470 & -1.128 & -0.647 & $-8.672 * *$ \\
\hline & $(18.30)$ & $(9.544)$ & $(4.828)$ & $(8.123)$ & $(3.538)$ \\
\hline State fixed effects & Yes & Yes & Yes & Yes & Yes \\
\hline Year fixed effects & Yes & Yes & Yes & Yes & Yes \\
\hline
\end{tabular}

Notes: Driscoll and Kraay (1998) robust standard errors in parentheses. Constant and fixed effects coefficients are not reported. $* * *$ Indicates significance at $1 \%, * *$ indicates significance at $5 \%, *$ indicates significance at $10 \%$. 
Table 7. The Effect of Term Limits on State Expenditures: 1972-2005.

\begin{tabular}{lcccc}
\hline & $\begin{array}{c}\text { Other } \\
\text { expenditures }\end{array}$ & $\begin{array}{c}\text { Other } \\
\text { expenditures }\end{array}$ & $\begin{array}{c}\text { State aid to } \\
\text { local } \\
\text { governments }\end{array}$ & $\begin{array}{c}\text { State aid to } \\
\text { local } \\
\text { governments }\end{array}$ \\
\hline Estimator & OLS & OLS-DK & OLS & OLS-DK \\
\hline Term limit & $1,497.4^{*}$ & $1,497.4^{* * *}$ & $1,117.3^{* *}$ & $1,117.3^{* * *}$ \\
& $(773.2)$ & $(362.3)$ & $(465.8)$ & $(226.0)$ \\
Term length & $-191.2^{*}$ & $-191.2^{* * *}$ & $-140.9^{* *}$ & $-140.9^{* * *}$ \\
& $(102)$ & $(48.64)$ & $(61.5)$ & $(30.64)$ \\
Tax \& expenditure limits & 0.92 & 0.917 & -1.15 & -1.151 \\
& $(1.71)$ & $(1.146)$ & $(1.59)$ & $(1.030)$ \\
GDP & $0.02^{* * *}$ & $0.0212^{* * *}$ & 0.004 & 0.00429 \\
& $(0.005)$ & $(0.00222)$ & $(0.003)$ & $(0.00264)$ \\
Federal aid & $0.36^{* * *}$ & $0.362^{* * *}$ & 0.15 & $0.151^{* * *}$ \\
& $(0.1)$ & $(0.0487)$ & $(0.11)$ & $(0.0442)$ \\
Unemployment rate & 8.56 & 8.562 & 3.34 & 3.338 \\
& $(6.82)$ & $(6.289)$ & $(8.4)$ & $(3.620)$ \\
Population 65+ & $1,767.4$ & $1,767.4 *$ & $-1,438.7$ & $-1,438.7^{* *}$ \\
& $(1,310.1)$ & $(885.2)$ & $(1,205.1)$ & $(612.7)$ \\
Population density & -0.26 & -0.258 & $-1.87 * *$ & $-1.869^{* * *}$ \\
& $(1.04)$ & $(0.265)$ & $(0.81)$ & $(0.271)$ \\
Divided government & -3.58 & -3.581 & 8.14 & 8.139 \\
& $(14.5)$ & $(13.28)$ & $(12.8)$ & $(8.702)$ \\
Governor democrat & -0.79 & -0.790 & 16.7 & 16.66 \\
& $(16.9)$ & $(9.343)$ & $(11.3)$ & $(10.18)$ \\
Governor lame duck & 19.6 & 19.63 & -2.3 & -2.290 \\
State fixed effects & $(19.3)$ & $(15.87)$ & $(9.21)$ & $(7.900)$ \\
Year fixed effects & Yes & Yes & Yes & Yes \\
\hline
\end{tabular}

Notes: Robust or Driscoll and Kraay (1998) standard errors in parentheses. Constant and fixed effects coefficients are not reported. $* * *$ Indicates significance at $1 \%, * *$ indicates significance at $5 \%, *$ indicates significance at $10 \%$. 
Figure 1. State Aid to Local Governments from 1970 to 2005

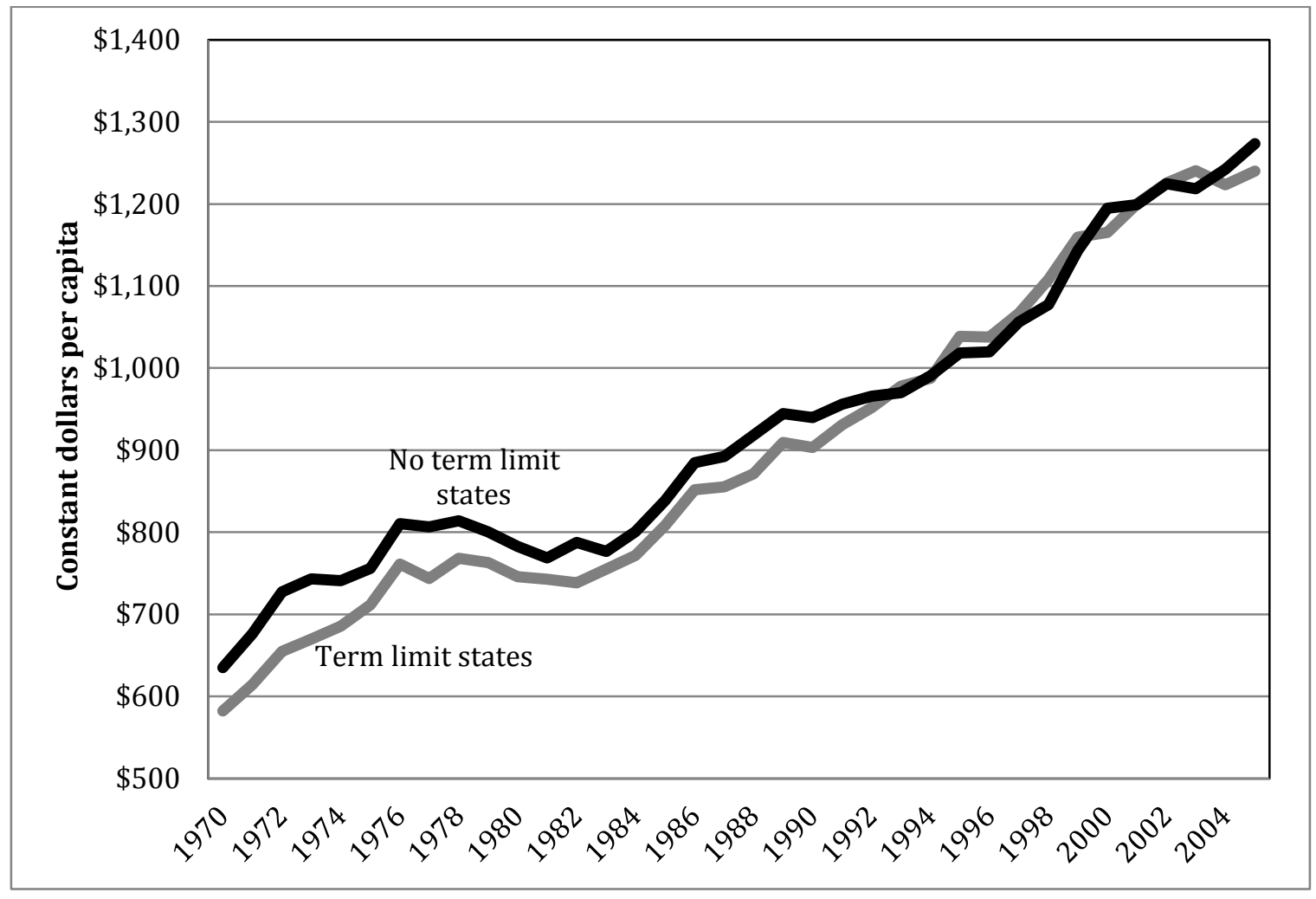

Source: U.S. Census Bureau. 